\title{
Exploring dissent in the Supreme Court of Argentina ${ }^{\text {th }}$
}

\author{
Sergio Muro ${ }^{\mathrm{a}}$, Sofia Amaral-Garcia ${ }^{\mathrm{b}}$, Alejandro Chehtman ${ }^{\mathrm{a}}$, Nuno Garoupa ${ }^{\mathrm{c}, *}$ \\ a Universidad Torcuato Di Tella, Argentina \\ b i3health, Université Libre de Bruxelles, Belgium \\ c George Mason University, Antonin Scalia Law School, United States
}

\section{A R T I C L E I N F O}

\section{Article history:}

Received 2 October 2019

Received in revised form 31 March 2020

Accepted 31 March 2020

\section{Keywords:}

Judicial behavior

Dissents

Argentina

\begin{abstract}
A B S T R A C T
When dissents are allowed, judges must decide whether or when to write them. While the main insights of rational dissent theory have been documented and corroborated in several empirical studies, there has been much less evidence testing on how different types of dissent may affect the likelihood of dissent. Particularly, dissents in more salient cases, or more forceful dissents, may have stronger legal effects than dissents appearing in less relevant cases or very narrowly construed dissents. Our article aims to fill that gap in the literature by seeking to isolate varying levels of appeal intensity and types of dissents in the Supreme Court of Argentina. Unlike previous literature, we find that more important cases have a lower likelihood of carrying a dissenting opinion. Yet, when we breakdown dissents by type (that is, reasoned dissents versus boilerplate dissents), we find that majority decisions carrying dissents tend to be longer, but only in cases of reasoned dissents. Furthermore, we show that reasoned dissents are more likely to occur in important cases. Overall, our study highlights that not all dissents should be treated alike as different types of dissent carry different levels of collegial and effort related costs. These costs affect the likelihood of dissent in different and complex ways.
\end{abstract}

(c) 2020 Elsevier Inc. All rights reserved.

\section{Introduction}

In collegial courts, judicial disagreement is inevitable. Legal systems address the possibility of judicial disagreement in a variety of ways. Early in its history, the Supreme Court of the United States replaced the traditional seriatim decision (in which each Justice enters her own opinion) with the current system of an opinion on behalf of the entire court with the opportunity for separate opinions (concurrences or dissents). In the United Kingdom, judges in the Appellate Committee of the House of Lords historically issued their decisions seriatim, a practice picked up by the new Supreme Court (Raffaeli, 2012). By contrast, in the French Cour de Cassation

\footnotetext{
We are grateful to two anonymous referees and the editor, Eric Helland, as well as Christian Abritta, Eduardo Baistrocchi, Alberto Garay, Hernan Gullco, and Héctor Mairal for useful discussions. We are also indebted to participants at the II Argentine Supreme Court International Conference at Universidad Torcuato Di Tella for comments and suggestions, particularly Lee Epstein and Tom Ginsburg. We are also grateful to participants at the Comparative High Court Decision Making Workshop in Jerusalem, particularly Udi Sommer. Constance L. McKinnon has provided superb research assistance. The usual disclaimers apply.

* Corresponding author.

E-mail addresses: smuro@utdt.edu (S. Muro), samaralgarcia@i3health.eu (S. Amaral-Garcia), achehtman@utdt.edu (A. Chehtman),ngaroup@gmu.edu (N. Garoupa).
}

deliberations are made secret by law and there are no dissenting opinions. ${ }^{1}$ Many other courts have mixed practices whereby dissents are allowed, but efforts are routinely made to find common ground and achieve consensus, as described in a media quote for the specific case of the Supreme Court of Argentina (Corte Suprema de Justicia de la Nación). ${ }^{2}$

It is a widespread characteristic that high courts are collegial in their nature of entertaining litigation under appeal. As they have increased responsibilities in error correcting and lawmaking, they tend to have more members than lower courts. Moreover, court decision is the outcome of collective deliberation. In effect, the specialized literature points out that a larger number of judges should improve accuracy in adjudication (Good and Tullock, 1984; Posner, 1985; Kornhauser and Sager, 1986; Shavell, 1995). Yet their collegial nature, together with the distinct role of high courts in any given legal system (addressing primarily points of law rather than

\footnotetext{
${ }^{1}$ See "The Role of the Court of Cassation", official document available at https:// www.courdecassation.fr/about_the_court_9256.html (last access October 15, 2018).

2 "The Supreme Court is a collegial court and we want to clarify public opinion that it is not a mere sum of individuals, although we are of different backgrounds. Dissents are respectfully casted and consensus is sought" Quote of Justice Highton de Nolasco, appearing in "Lorenzetti, el nuevo presidente," page 12, Wednesday November 8th 2006. The same article describes Justice Lorenzetti as "consensus seeker."
} 
assessing facts), seems prone to a degree of internal judicial disagreement. At the same time, there are norms of consensus in all legal systems (Gerber and Park, 1997). Too much disagreement is intuitively dysfunctional and excessively costly. So, within an efficiency theory of court norms, some pressure for consensus is clearly rational.

Jurisdictions around the globe (and across time) ${ }^{3}$ have different approaches towards disagreement within a court. While the practice of producing and publicizing dissents is extended across common law countries, the tradition in civil law jurisdictions was to prohibit dissenting opinions (Fon and Parisi, 2006). Still today, in the case of the Belgian Court of Cassation or the Italian Constitutional and Cassation Courts, publishing individual views of judges made in secret deliberations constitutes a criminal offense (Raffaeli, 2012). ${ }^{4}$

When dissents are allowed, judges must decide whether or when to write them (Wood, 2012). This depends on a set of determinants, including limited resources, extent of the disagreement, internal practices of the court, and working environment. Rational dissent theory (Epstein et al., 2011; Fischman, 2011; Edelman et al., 2012) explains these determinants with a model of self-interested federal judges who enjoy life tenure. In this model, as judges make the decision whether or not to dissent, they trade off their desire for leisure and good collegial relations with their aspiration for a good reputation and their willingness to express their opinion to influence the law. ${ }^{5}$ As a result, judges may choose not to dissent even if they do not share the opinion of the majority. Epstein et al. (2011) refer to this as dissent aversion: Tests of rational dissent theory have shown that the probability of dissent is influenced positively by the ideological differences among judges (Epstein et al., 2011), the number of judges in the court or panel (Hazelton et al., 2017), and the importance of a case (Epstein et al., 2011); and negatively by the size of the caseload (Epstein et al., 2011) and by sociodemographic variables (for example, whether judges work in the same city; Hazelton et al., 2017). ${ }^{6}$ Others have emphasized other costs generated by dissenters, such as the harm they may cause to a court's perceived legitimacy or reputation (Stack, 1996).

While the main insights of rational dissent theory have been documented and corroborated in several studies, there has been much less empirical testing on how different types of dissent may affect the likelihood of dissent. Dissents in more salient cases, or more forceful dissents, may have stronger legal effects than dissents appearing in less relevant cases or very narrowly constructed dissents. Our article aims to fill that gap in the literature by seeking to isolate varying levels of appeal intensity and types of dissents in the Supreme Court of Argentina.

The Supreme Court of Argentina is a collegial high court with discretionary appellate jurisdiction. It reviews constitutional and federal questions potentially impacting many other cases ${ }^{7}$ as well as due process adjudication (whose effects are restricted to the appeal at stake). In addition, the Court issues rulings on appeal's admissibility and on the substance of the case within the same deci-

\footnotetext{
3 See Epstein et al. (2011).

4 Art. 685 of the Italian Criminal Code criminalizes the publication of the names and votes of judges sitting in criminal cases. However, since 1988 (when the new law on judicial civil liability was enacted), dissents, and the grounds therefore, may be recorded, upon the dissenter's request, but are kept in a sealed envelope.

5 Fischman (2011) conceptualizes the trade off in terms of suppressed dissent, which occurs when a judge decides to join a majority even if her preferred outcome would differ from the one voted by her colleagues.

${ }^{6}$ Earlier papers (Walker et al., 1988) discussed the possibility that a more significant caseload could enhance levels of individual expression, as judges would not have the time to build consensus and construct compromises.

7 While Argentina's formal lack of stare decisis means that the Court's decisions are not binding on other courts, the decisions on constitutional or federal questions carry significant authoritative value. See Section 3 below.
}

sion. These special features allow us to identify different types of dissents (for example, certiorari denied or boilerplate dissents vs reasoned dissents) as well as cases with different level of importance (for example, federal or constitutional appeals versus due process violations).

In contrast to common wisdom and previous empirical literature, our main finding is that more important cases have a lower likelihood of carrying a dissenting opinion. Yet, when we breakdown dissents by type (that is, reasoned dissents versus boilerplate dissents), we find that majority decisions carrying dissents tend to be longer, but only in cases of reasoned dissents. Furthermore, we show that reasoned dissents are more likely to occur in important cases, suggesting that Justices choose to exert the effort needed to produce a reasoned dissent when the potential net benefits are higher, for example, in terms of legal aspiration. Overall, our study highlights that not all dissents should be treated alike as different types of dissent carry different levels of collegial and effort related costs. These costs affect the likelihood of dissent in different and more complex ways than previously anticipated.

The paper proceeds as follows. In Section 2 we present the legal and institutional background of the Supreme Court of Argentina. In Section 3 we present the theoretical framework and construct our hypotheses. In Section 4 we succinctly describe our data. Sections 5 and 6 present our main findings. Section 7 briefly concludes.

\section{Supreme Court's institutional context}

In this section, we briefly explain the Supreme Court's procedural rules and describe its organizational structure and jurisdiction. The Supreme Court of Argentina intervenes both through its original jurisdiction (that is, first instance court in very specific matters) and as the appellate court of last resort. ${ }^{8}$ Only the latter is relevant for our purposes here. ${ }^{9}$ The Supreme Court's appellate jurisdiction ${ }^{10}$ includes cases decided by courts of federal, national (i.e., local courts of the city of Buenos Aires), ${ }^{11}$ federal/national (i.e., criminal cases from federal or national standing that reach the Federal Criminal Cassation Court), or provincial jurisdiction.

The standard appellate jurisdiction is known as Extraordinary Appeal (Recurso Extraordinario Federal; hereinafter, REF) and it has three different sources. One possibility arises when a case questions the validity of a treaty, federal law or action undertaken under federal authority and the local court holds against the validity of the treaty, law or the federal authority. A second alternative arises when the validity of a provincial law, decree or act has been questioned as unconstitutional or contrary to a treaty or federal law, and the provincial court decides in favor of the validity of the provincial measure. Finally, the Supreme Court may intervene when a party invokes a constitutional clause, treaty, law, or grant of federal authority and the provincial court decides against the norm or

\footnotetext{
${ }^{8}$ When the Argentine parliament established the Supreme Court appellate jurisdiction, it followed closely the U.S. Judiciary Act of 1789 .

${ }^{9}$ Its original jurisdiction is used for cases related to foreign ambassadors, ministers or consuls, or cases between provinces or a province and a foreign state Constitution of Argentina, article 117 and article 1 of Act 48 (Organización y Competencia de los Tribunales Nacionales).

${ }^{10}$ In most of these cases, the Supreme Court possesses appellate jurisdiction, save for those cases concerning foreign ambassadors, ministers and consuls, and in those cases in which a province shall be a party, where the Court has original and exclusive jurisdiction. See article 117 of the Constitution of Argentina. An unofficial English version of the Constitution is available at http://www.biblioteca.jus.gov.ar/ argentina-constitution.pdf (last access October 15, 2018). See, accordingly, article 1 of Law $\mathrm{N}^{\circ} 48$, available in Spanish at http://www.infoleg.gov.ar/infolegInternet/ anexos/115000-119999/116296/texact.htm (last access October 15, 2018).

11 Article 4 of Law $\mathrm{N}^{\circ} 48$.
} 
privilege invoked. ${ }^{12}$ Under exceptional circumstances, an appeal may be granted on the grounds that the decision of the lower court was arbitrary (Recurso Extrarodinario por sentencia arbitraria, hereinafter, Arbitrariedad). ${ }^{13}$

In order to reach the Supreme Court, petitioners must file complaints - commonly referred to as Recurso extraordinario (hereinafter, REX) - in the relevant lower court of appeal (or provincial supreme court), which decides whether the appeal meets the substantive and procedural requirements after affording an opportunity for respondents to file appropriate replies. If the lower court determines that all requirements are satisfied, the appeal is sent to the Supreme Court. If the lower court determines they are not, the appeal is denied; in that case, litigants may directly ask the Supreme Court to reconsider their cases through a Recurso de Queja (hereinafter, RHE). In this case, the Supreme Court will review whether the lower court legitimately denied the appeal.

Once the appeal reaches the Supreme Court, it is distributed to the Judicial Department specialized in the specific area of the appeal. ${ }^{14}$ The relevant Judicial Department conducts a preliminary assessment on the basis of the formal requirements. ${ }^{15}$ The specialized Judicial Department often keeps the file for internal drafting before circulating it among the justices if the appeal arrives through RHE. When the appeal is granted by the lower court, the specialized Judicial Department usually distributes it across the justices, often starting with one with particular specialization in an area (before going to the others ). ${ }^{16}$ An initial majority draft is crafted in the office of the first Justice to review a REX appeal. If a Justice proposes a different solution that second opinion is added to the circulating file. Eventually, the latter opinion may become the majority opinion.

There is no rule that limits the period during which (or the number of times) a file may circulate among Justices. In addition, Arbitrariedad and REF files will typically be sent to the office of the Procurador General de la Nación (hereinafter, Procurador General) for a non-binding opinion. ${ }^{17}$ Each Justice will usually make a decision on the petition after reviewing the appeal file by issuing (or joining in) a reasoned or boilerplate opinion, or by reference to a previous case decision or the non-binding opinion of the Procurador General. ${ }^{18}$ Referencing in this context means that a decision or vote will merely invoke a previous decision or opinion as the grounds for the present ruling, without explaining how or why it applies to the particular circumstances. Justices opinions may come in the form of a majority vote, a separate concurring vote (classified by the Supreme Court as por su voto), a dissenting vote (partial or total) (classified by Supreme Court as either en disidencia or en disiden-

\footnotetext{
12 Article 14 of Law $\mathrm{N}^{\circ} 48$, available in Spanish at http://www.infoleg.gov.ar/ infolegInternet/anexos/115000-119999/116296/texact.htm (last access October 15, 2018).There is a separate kind of mandatory appellate jurisdiction known as ordinary appeals, which are reserved for cases in which the state is a party and the amount of the claim exceeds a certain figure. This latter form of appellate jurisdiction is subjected to different rules. It is not addressed in this study.

13 See, e.g., Supreme Court decisions in Fallows 302:1191, and Fallos 300:535.

14 A description of the thematic area of specialization of each Judicial Department is available upon request.

15 On the appeal document's formal requirement, see Muro et al. (2018).

16 Tax law appeals are always analyzed by the relevant Judicial Department (Secretaría Judicial $\mathrm{N}^{\circ}$ 7). Interview $\mathrm{A}-3$.

17 The Procurador General is often equated to the figure of the Attorney General in the US. It formally sits outside the structure of the executive and judicial power and is charged with the protection of the general interests of society and the defense of the constitution (see Article 120, Constitution of Argentina.) The Procurador General is nominated by the president, and is confirmed by two thirds of the members of the Senate.

18 It should be noted that there is no rule mandating a minimal amount for circulation of each file or that each Justice should receive the file through the circulation process.
}

cia parcial) or even a no vote. ${ }^{19}$ Formally, the decisions are taken on Tuesdays when Justices officially get together to sign the opinions they have made on the different cases. Such meetings may also serve to discuss other cases in the pipeline. ${ }^{20}$ Proper hearings are extremely rare. ${ }^{21}$

The fact that the Supreme Court has jurisdiction over a case does not guarantee that the Court will arrive at a decision on the intrinsic merits of the appeal. In 1990, Congress reformed the Code of Civil and Commercial Procedure, giving the Supreme Court discretion to dispose of appeals based on a lack of substantive importance. ${ }^{22}$ This type of decision is referred to as Article 280. Since then, the Supreme Court has routinely made use of the discretionary power to reject appeals on the grounds that the matters raised by the appellant are either insignificant or inconsequential. In order for the Supreme Court to reject an appeal it must deliver a decision, ${ }^{23}$ typically of the boilerplate type. Rulings on an appeal's admissibility and, eventually, on the substance of the case are included in the same decision. As a result, some admitted appeals carry Article 280 dissents and some rejected appeals have dissents admitting the appeal and analyzing the merits. At the time of our study, the Supreme Court had seven members. In practical terms, this means that at least four Justices had to vote in order to produce a legal outcome. ${ }^{24}$

\section{Theory and hypotheses}

\subsection{Review of the Literature}

The normative debate surrounding the possibility of dissent has a long history. Arguments in favor of voicing dissent are rooted in free speech and judicial independence (Vitale, 2014), the moral obligation a Justice has when her interpretation differs from the majority (Brennan, 1985), an outcome consisting of a better argued majority opinion (Haire et al., 2013), and the benefits for the evolution of the law (McCormick, 2012). Arguments in favor of decisions per curiam are based on the negative effects dissents may pose on public confidence in the court and court legitimacy (Stack, 1996; Zink et al., 2009; Salamone, 2013), legal certainty, efficient use of court resources (Vitale, 2014) and compliance with court decisions (Naurin and Stiansen, 2016).

While the debate regarding the overall benefits of dissents is far from settled, when judges do have the option to dissent available to them, they face a somewhat complex choice (Berzon, 2012; Wood, 2012). According to rational dissent theory (Edelman et al., 2012; Epstein et al., 2011; Fischman, 2011; Niblett and Yoon, 2015), a potential dissenter must balance the costs and benefits of actually writing a dissenting opinion. As such, a potential dissenter recognizes that reaching a different outcome than the majority of the court requires effort, which represents an important cost. Furthermore, the dissenting vote will demand additional effort from the majority to answer the arguments of the dissenter (either in terms of revising the original opinion to accommodate the point of view

\footnotetext{
19 Not voting on a case is a fairly widespread practice in Argentine collegial courts, commonly attributed to the large docket sizes those courts handle.

${ }^{20}$ When discussing cases, Justices may question officers leading the relevant specialized Judicial Departments on the details of the case. Informal meetings where Justices (or their clerks) discuss cases are somewhat frequent.

21 On this, see Benedetti and Saenz (2016).

22 Articles 280 and 285, Código de Procedimiento Civil y Comercial de la Nación Ley 23.774 (1990), available in Spanish at http://www.infoleg.gov.ar/infolegInternet/ anexos/15000-19999/16547/texact.htm\#5 (last access on March 15, 2018).

23 Notably, this type of decision has the same majority requirements as a decision on the merits.

24 In 2014, the Supreme Court composition was reduced from seven to five justices. Hence, with the new composition, at least three justices have to vote now to reach a decision. It should also be noted that a majority vote is reached for dismissal even if a vote provides other grounds for appeal dismissal in a separate opinion.
} 
of the dissenter or to respond to her objections). Repeated or forceful dissents may make it more difficult for the dissenter to gain the support of her peers in future cases and may even affect job satisfaction (Epstein et al., 2013), generating a collegiality cost. Finally, dissents may harm the legitimacy of the court (Salamone, 2013) and even diminish the probability of compliance with its orders (Naurin and Stiansen, 2016).

Against these costs, potential dissenters assess the benefits of a dissenting opinion. These benefits include the desire for a good judicial reputation and to express their opinion - which may include the satisfaction for doing so or the chance to influence the case law (Wahlbeck et al., 1999; Harnay and Marciano, 2003; Hettinger et al., 2004; Sunstein, 2015). After balancing these costs and benefits, a judge may ultimately forgo the opportunity to dissent even if her ideological preference is different from the one expressed by the majority vote.

Researchers have found evidence supporting the validity of some testable hypotheses emanating from rational dissent theory. First, and as per costs of dissent, Epstein et al. (2011) found that caseload is negatively related to the probability of dissent at both Supreme Court and appellate courts, suggesting that the marginal cost of writing a dissenting opinion increases with a heavier workload. At the U.S. Supreme Court level, Epstein et al. (2011) found evidence for the additional effort demanded from the supporting judges as majority opinions tend to be longer when more than one dissent is present. Similarly, they found that majority opinions in U.S. appellate courts are longer when there is a dissenting opinion. In terms of collegiality costs, Hazelton et al. (2017) document that U.S. Court of Appeals judges who work in the same city are less likely to dissent with one another. They also showed that judges on circuits with fewer active judges, who are more likely to be in a panel together in the future, as well as judges who have served longer with other judges in the same circuit, are less likely to dissent with one another. ${ }^{25}$

Second, Epstein et al. (2011) provided evidence on the benefits of dissenting. In their study, dissent at the appellate courts slightly increases the chances that the Supreme Court will grant certiorari. Those dissents are rarely cited inside or outside the circuit, diminishing the likelihood of reputation-building or of influencing the law. In the case of the Supreme Court, when a decision has more than one dissenting opinion or when the case is more important (proxied by the number of citations received by the majority opinion) it increases the likelihood of citing those dissents. In the same vein, McCormick (2012) found that an initial minority became a majority in roughly one in every four divided panels in the Supreme Court of Canada. ${ }^{26}$

\subsection{Theory}

While rational dissent theory accounts for costs and benefits, the prevailing way for empirically accounting for these costs and benefits has not been particularly granular. Specifically, how different types of cases and petitions shape the likelihood of dissent is an open question. On the one hand, a dissent that is unduly critical of the majority opinion ${ }^{27}$ may not be received as lightly as one that accounts for the complexity of the issue and makes an effort to limit the areas of disagreement. On the other hand, it is implausible that dissenter is oblivious to the importance of a case. Even if the level of criticism in a dissenting opinion remains constant, a dissent that appears in an important or salient case may generate more collegiality costs or harm to the legitimacy of the court than others. It could also offer higher reputational rewards.

We can, therefore, suggest two different relevant decisions. First, judges must consider whether or not to dissent. According to rational dissent theory, they will balance costs and benefits. Therefore, judges should dissent in cases where the possible benefits (for example, impact on the law or external recognition) outweigh costs. Second, if dissenting, judges must decide which kind of dissent to cast - a long, detailed, reasoned dissent or a boilerplate dissent. By backwards induction, the decision on whether or not to dissent should take into account the subsequent decision concerning type of dissent.

Let us assume that a dissent is being drafted. A rational judge would go for a reasoned dissent when the matter justified a long, legal pondering of arguments. The same rational judge should opt for boilerplate dissents when the case does not answer a very important legal question. The immediate consequence of these observations is that dissenting in important matters is costlier (because it involves long and complex reasoned dissents) while dissenting in less important cases is less costly (since the judge will file something like a template).

At the same time, we can envisage that individual benefits from dissenting are also more acute in important cases (at least, in terms of external visibility) than in less important cases (which have little impact on the law or on legal and political debates).

Therefore, rational dissent theory cannot predict the exact outcome on the balance of costs and benefits. In fact, it could be that the net benefit is positive for important cases (because legal impact is more significant than drafting a reasoned dissent), for less important cases (because filing a boilerplate dissent is almost costless), or for both. Apparently only empirical evidence can respond to this question.

The Supreme Court of Argentina's institutional setting allows us to investigate these matters. A key element of the institutional setting is that the process is primarily written (not oral, as in common law systems) and the role for litigants, albeit in a few exceptional cases, ${ }^{28}$ is limited to the filing of the appeal and the written response. The norm, then, is for the Supreme Court to decide on appeal admissibility and on the substance of the case (if necessary) in the same decision. Consequently, dissenting opinions may consist of argued positions on the subject matter or merely a denied certiorari. A denied certiorari dissent typically does not include an explanation as to why the appeal should be dismissed. As a result, such a dissent should demand less from the Justices in the majority who do not have to respond to any particular argument.

The Supreme Court issues three types of decisions on extraordinary appeals. ${ }^{29}$ REF decisions involve appeals concerned with constitutional review while Arbitrariedad decisions focus on whether or not the inferior court's decision was arbitrary, typically due to violations of due process or the right to a reasoned opinion. In turn, Article 280 decisions are certiorari denied cases (based on lack of substantive importance of the appeal). As a result, $R E F$ appeals involve constitutional or federal issues, typically raising questions about fundamental values. This is often not the case with Arbitrariedad cases. Furthermore, while Argentina does not formally recognize stare decisis, $R E F$ precedents typically carry greater authoritative value and are more often than not followed by lower

\footnotetext{
28 See Benedetti and Saenz (2016).

29 The Supreme Court also issues decisions to dismiss appeals on formal grounds, for instance when the appeal document did not comply with certain requirements or for lack of autonomous reasoning (Muro et al., 2018).

\footnotetext{
25 Hazelton et al. (2017) found a similar co-tenure effect in the Supreme Court.

${ }^{26}$ Other commonly intervening factors seem to play a role in dissents too. For instance, Epstein et al (2011) showed that ideological differences among judges at both Supreme Court and appellate courts increase the chances of a dissent.

27 See Vitale (2014) for illustrative examples of accusations of improper motives and other unduly criticisms.
} 
courts. ${ }^{30}$ Arbitrariedad decisions, by the nature of the underlying appeal, apply merely to the case in question or at stake. ${ }^{31}$ Finally, Article 280 decisions apply to both appeals asking for constitutional review or to overturn an arbitrary decision and are issued when a majority of Justices believes that the appeal lacks substantive importance. By definition, Article 280 cases are those whose importance does not warrant the attention of the Court. Combined, these reasons suggest that $R E F$ cases are, on average, more important than Arbitrariedad, and that each of them is, in turn, more important than Article 280 appeals.

\section{Data collection and processing}

The focus of this study is on individual votes concerning the decisions (REF, Arbitrariedad and Article 280) arising out of extraordinary appeals (REX and RHE) issued by the Supreme Court of Argentina in 2012 and 2013, i.e., in the subset of cases where litigants decided to appeal to the Supreme Court. ${ }^{32}$ The Supreme Court publishes every opinion it issues online, along with information on case history and other background information. Starting in 2012, the Supreme Court's jurisprudence office has categorized every opinion according to different criteria. It also introduced a search engine, which allows users to search for opinions meeting any of the pre-determined criteria. One such criterion is the outcome of the opinion. We used the search engine to find every decision on Arbitrariedad and REF grounds that Supreme Court made during 2012 and 2013, excluding pension cases. ${ }^{33}$ In addition, we randomly selected one fourth (500) of all opinions issued in 2012 decided on Article 280 grounds, again excluding pension cases. ${ }^{34}$ After discarding repeated opinions and opinions that were mistakenly classified as Arbitrariedad, Article 280 or REF, we ended up with a working database consisting on the following decisions: 918 REF, $320 \mathrm{Arbi-}$ trariedad, 496 Article $280 .{ }^{35}$ Given the methodology used, we find this to be consistent with a random sampling for the purpose of statistical testing.

Because we were interested in looking at an individual level information to assess the factors shaping the probability of dissent, we then assessed the data to capture the votes of each Justice in every single case. We classified individual votes as dissents (total or partial) and classified separate concurring opinions following the Supreme Court's own classification. This procedure resulted in

\footnotetext{
30 See Legarre (2011); interview with Cristian Abritta, a former senior officer of the Supreme Court (retired in 2018).

31 See, classically, Carrió (1967)

32 The Supreme Court decides thousands of appeals each year. During the 2012-3 period, the court issued about 14,000 decisions, including pension cases. Most of those decisions (83\%) were appeal dismissals. At the time, about half of the court's decisions to dismiss appeals were boilerplate decisions on procedural grounds (such as for failing to comply with formal requirements or failing to produce a selfcontained appeal document). The rest were certiorari denied decisions based on Article 280.

33 Pension cases are somewhat particular and therefore we decided to exclude them from the analysis. Specifically, almost every pension case arises out of disputes between pensioners and the government due to lack of adjustments made to the pension amount over the years. Typically, lower courts would order the government to adjust those amounts according to a specific criterion and the government has adopted a policy which mandates its legal department to appeal each case up to the Supreme Court. Therefore, there are thousands of similar cases reaching the Supreme Court each year which do not merit much attention for present purposes.

${ }^{34}$ For data availability issues, we only used Article 280 decisions from 2012. As these are certiorari denied opinions, we have no reason to believe the decisions in 2013 (or other years) would differ in terms of dissent probability or average length of the opinion.

35 The cases identified by the methods described above were coded by student research assistants. Prior to the student coding, the authors developed a template to structure the coding and a coding protocol. After review of the performance of the form, the protocol and the students in an initial set of cases, the form and the protocol were revised. The students used that revised form and protocol to code the cases, under the supervision of the authors.
}

Table 1

Number of decisions by appeal type and decision type.

\begin{tabular}{lll}
\hline & 2012 & 2013 \\
\hline $\boldsymbol{R E F}$ & 314 & 379 \\
REX & 107 & 118 \\
RHE & & \\
Arbitrariedad & 82 & 82 \\
REX & 86 & 70 \\
RHE & & \\
Article 280 & 105 & 0 \\
REX & 391 & 0 \\
RHE & & \\
\hline
\end{tabular}

Table 2

Percentage of decisions by type and subject area.

\begin{tabular}{llll}
\hline & REF & Arbitrariedad & Article 280 \\
\hline Bankruptcy/Corporate Law & 0.03 & 0.02 & 0.03 \\
Civil Procedure & 0 & 0 & 0 \\
Constitutional Law/Health Law & 0.03 & 0.03 & 0.01 \\
Contract Law/Financial & 0.01 & 0.06 & 0.03 \\
$\quad$ Contracts/ Consumer Law & & & \\
Criminal Law/Criminal & 0.06 & 0.12 & 0.39 \\
$\quad$ Procedure & & & \\
Family Law/Estates & 0.01 & 0.01 & 0.02 \\
Human Rights Law & 0.03 & 0.01 & 0.02 \\
Labor Law & 0.08 & 0.13 & 0.16 \\
Property Law & 0.1 & 0.02 & 0.04 \\
Public/Antitrust Law & 0.46 & 0.15 & 0.15 \\
Social Security Law & 0 & 0 & 0 \\
Tax Law & 0.16 & 0.02 & 0.11 \\
Tort/Insurance Law & 0.04 & 0.44 & 0.05 \\
\hline
\end{tabular}

a database consisting of the following individual votes: $6426 R E F$, 2240 Arbitrariedad and 3472 Article 280.

\section{Results}

The object of this article is to assess the effects of different cases and dissents on the probability of dissent. To address this issue, we started with a database of extraordinary appeal decisions which excluded those decisions rejecting appeals on formal grounds. ${ }^{36}$ Table 1 describes the decisions in our database. REF decisions comprise $53 \%$ of the total number of decisions used in this article, while Arbitrariedad and Article 280 represent $18 \%$ and $29 \%$ respectively. Most REF decisions originated out of appeals granted by the lower courts (i.e., REX appeals - about 75 \%), while most Article 280 decisions arose from direct appeals (i.e., RHE appeals - about $78 \%$ ). Taken together, these figures suggest a certain level of agreement between lower courts and the Supreme Court on which appeals should be entertained by the highest court, as the Supreme Court only gets to review REX appeals when a lower court grants the leave for appeal. Arbitrariedad decisions are more evenly distributed, with $51 \%$ of them arising from REX appeals.

Table 2 reports the number of decisions issued according to the subject matter of appeals and categorized according to the type of decision. The prominence of subject areas varies greatly with the type of decision. For instance, $46 \%$ of REF decisions (418) came about on the public/administrative law area. In turn, tort/insurance law is the most frequent subject matter area in Arbitrariedad decisions, accounting for $44 \%$ (137). Finally, Article 280 decisions most frequently appear in criminal law/criminal procedure appeals.

Consistent with a court that aims for consensus, dissenting votes are somewhat rare. Only $4 \%$ of the Justices' votes come in the form of a dissenting or partially dissenting opinion. Dissenting votes are

\footnotetext{
36 There are several formalities appeals must comply with in order to be reviewed.
} For more on this point, see Muro et al. (2018). 
Table 3

Proportion of dissents or partial dissents by area of law and decision type.

\begin{tabular}{lll}
\hline & No dissent & Partial or total dissent \\
\hline REF & & \\
Private Law & 0.99 & 0.01 \\
Constitutional Law & 0.96 & 0.04 \\
Criminal Law & 0.92 & 0.08 \\
Labor Law & 0.95 & 0.05 \\
Public/Tax Law & 0.97 & 0.03 \\
Arbitrariedad & & \\
Private Law & 0.9 & 0.1 \\
Constitutional Law & 0.86 & 0.14 \\
Criminal Law & 0.88 & 0.12 \\
Labor Law & 0.87 & 0.13 \\
Public/Tax Law & 0.95 & 0.05 \\
Article 280 & & \\
Private Law & 0.99 & 0.01 \\
Constitutional Law & 1 & 0 \\
Criminal Law & 0.98 & 0.02 \\
Labor Law & 1 & 0 \\
Public/Tax Law & 0.97 & 0.03 \\
\hline
\end{tabular}

somewhat rare in all types of decisions, though they seem to appear more frequently in Arbitrariedad votes (10\%). By contrast, only $2 \%$ of $R E F$ votes and only 3\% of Article 280 votes are dissenting ones. As Table 3 shows, dissenting votes are rare in all areas of the law, although more prominent in criminal law (except for Article 280 decisions).

In order to assess dissent probability, we started by looking at appeals potentially carrying different weights. REF decisions typically involve constitutional or federal questions and tend to have an authoritative effect on lower courts handling similar cases. Arbitrariedad decisions generally involve due process violations and their effects are limited to the case at stake. In turn, Article 280 (i.e. certiorari denied) decisions arise out of appeals lacking substantive importance, as determined by the majority of the Court. Hence, we expect more important REF cases to involve higher rewards for dissenters but also to produce higher collegiality costs. At the other end of the spectrum, we expect dissents in Article 280 decisions to carry lower rewards and lower collegiality costs. As it was described in Table 3, dissents appear to be more frequent in Arbitrariedad cases. To test this issue in a multivariate context, we run several binomial multiple regression models. The dependent variable takes value " 1 " if a dissenting or partially dissenting vote is cast and " 0 " otherwise (including no vote). ${ }^{37}$ Our main independent variable is decision type, a categorical value with three levels (REF, Arbitrariedad and Article 280).

To account for Supreme Court's institutional setting, appeal, and Justices' characteristics, we also included several control variables in different specifications. As previous studies found ideology to play a role, we included a variable called Justice distance to median based on Gonzalez-Bertomeu et al. (2017), which captures the distance between each Justice and the median Justice. It measures some form of more radical judicial philosophy, therefore we expect it to have a positive impact on the probability of dissent.

Seniority may be related to less pressure to join the majority, so we have the variable Justice's seniority. Similarly, we included a dummy variable Supreme Court pres in majority to account for the cases with Chief Justice Lorenzetti in the majority. Due to the possibility that dissent may be affected by the participation of the executive branch in the appeal, we included a dummy variable national government as party. More complex cases may require additional study at each Justice's office. Hence, we included a vari-

\footnotetext{
37 We have considered binomial logit regressions when "no vote" is excluded. The results are largely consistent with tables $4-5$. The number of individual observations is reduced from 11,102 to 7,643 .
}

able capturing the number of times an appeal file circulated through a Justice's offices (total times at Justices offices). To capture the effect of previous references (i.e. deciding by merely invoking a previous decision or opinion) by the majority opinion (a common practice in Supreme Court), we included two dummy variables for possible references: reference to Procurador General and reference to a previous Supreme Court decision. Given that separate concurring opinions may also have an effect on dissent probability, we incorporated a dummy variable called separate opinion, which is equal to one if there is at least one other judge on the panel presenting a separate concurring opinion and zero otherwise. ${ }^{38}$ Similarly, we added a dummy variable called additional dissents to control for those decisions containing more than one dissenting vote. To account for possible differences between appeals granted by the lower court and direct appeals, we included a dummy accounting for appeals granted by the lower courts (REX) and direct appeals (RHE). We also included a dummy variable for decisions issued in 2013 (decision in 2013) to capture any possible caseload effects. ${ }^{39}$ To capture the subject matter of each appeal we included Judicial Department's fixed effects. Finally, we also controlled for the rapporteur in each Supreme Court's decision. For the sake of independence, all standard errors are clustered on each Supreme Court's decision. ${ }^{40}$

Table 4 shows the logistic regression results. Notice that two variables, total times at Justices offices and separate opinions, are excluded in column (1) due to the possibility that they are influenced by the main variable of interest. By observing columns (2)-(7), we can conclude that it makes no difference in terms of general results. Consistent with the descriptive statistics presented in Table 3, when compared to REF decisions, Arbitrariedad cases are associated with higher probability of dissent in all seven specifications. This result is highly significant in all regression specifications (p-value < 0.01). In turn, Article 280 is associated with a lower chance of dissent in five specifications ( $\mathrm{p}$-value $<0.01$ ). Ideological extremism (measured in terms of distance to the median Justice) is positively related to the probability of dissent in a highly statistically significant manner ( $p$-value $<0.01$ ) and in all specifications. The dummy for the year of the decision, as well as the control for Justice seniority, fail to show any statistically significant effect on the probability of dissent. As per decisions based on references, the decisions with references to the Procurador General are negatively related to the probability of dissent in all seven specifications ( $\mathrm{p}$ value $<0.01$ ). Interestingly, decisions with references to previous decisions fail to show any statistically significant difference in dissent probability, suggesting that dissents in the remitted decision tend to be replicated in later cases. Cases that originated in Judicial Department N4 (administrative law cases) and Judicial Department N7 (tax law cases) were associated with a lower probability of dissent compared to cases that went through Judicial Department N5 (p-value $<0.1$, in all but two specifications). Direct appeals to the Supreme Court (RHE), arising after a lower court rejected the grant of leave for appeal petition, are less likely to generate a dissenting vote ( $p$-value $<0.05$ in all but three of the regression specifications).

Let us now consider variables excluded from the base regression by analyzing column (2) to (7). Case complexity, as proxied by Total times at Justices offices, is positively related to the likelihood of dissent in four specifications ( $\mathrm{p}$-value $<0.01$ ). Decisions

\footnotetext{
38 On separate concurring opinions, see Amaral-Garcia and Garoupa (2017).

39 The Supreme Court publicizes only information on decisions issued. Hence, it is not possible to precisely assess its caseload on a given year.

40 Notice also that we run several specifications in order to acknowledge that some variables might raise concerns in terms of identification. Our main variable of interest (decision type) could potentially be influencing the existence of separate opinions or additional dissents, as well as the number of times a file circulated through Justice's offices. Hence, our base regression does not include any of these control variables. The results obtained are consistent across different specifications.
} 
Table 4

Binomial logit regression results.

\begin{tabular}{|c|c|c|c|c|c|c|c|}
\hline & \multicolumn{7}{|c|}{ Dependent variable: } \\
\hline & \multicolumn{7}{|c|}{ Dissent or partial dissent $=1$} \\
\hline & (1) & $(2)$ & (3) & $(4)$ & $(5)$ & $(6)$ & (7) \\
\hline \multirow[t]{2}{*}{ Justices distance to median } & $0.712^{* * *}$ & $0.719^{* * *}$ & $0.719^{* * *}$ & $0.719^{* * *}$ & $0.723^{* * *}$ & $0.942^{* * *}$ & $0.547^{* * *}$ \\
\hline & $(0.053)$ & $(0.053)$ & $(0.053)$ & $(0.053)$ & $(0.061)$ & $(0.080)$ & $(0.085)$ \\
\hline \multirow[t]{2}{*}{ Arbitrariedad } & $0.979^{* * *}$ & $1.032^{* * *}$ & $1.010^{* * *}$ & $1.004^{* * *}$ & $0.949^{* * *}$ & $1.066^{* * *}$ & $0.726^{* * *}$ \\
\hline & $(0.156)$ & $(0.156)$ & $(0.158)$ & $(0.158)$ & $(0.178)$ & $(0.154)$ & $(0.176)$ \\
\hline \multirow[t]{2}{*}{ Article 280} & $-1.342^{* * *}$ & $-0.992^{* * *}$ & $-1.023^{* * *}$ & $-0.980^{* * *}$ & $-1.093^{* * *}$ & -0.436 & $-0.494^{*}$ \\
\hline & $(0.312)$ & $(0.335)$ & $(0.336)$ & $(0.344)$ & $(0.415)$ & $(0.283)$ & $(0.257)$ \\
\hline \multirow[t]{2}{*}{ Reference to Procurador General } & $-0.832^{* * *}$ & $-0.920^{* * *}$ & $-0.927^{* * *}$ & $-0.922^{* * *}$ & $-1.051^{* * *}$ & $-0.509^{* * *}$ & $-0.661^{* * *}$ \\
\hline & $(0.213)$ & $(0.205)$ & $(0.205)$ & $(0.206)$ & $(0.249)$ & $(0.183)$ & $(0.177)$ \\
\hline \multirow[t]{2}{*}{ Reference to previous decision } & $-0.292^{*}$ & 0.062 & 0.053 & 0.048 & 0.073 & 0.069 & -0.102 \\
\hline & $(0.168)$ & $(0.180)$ & $(0.180)$ & $(0.180)$ & $(0.215)$ & $(0.167)$ & $(0.155)$ \\
\hline \multirow[t]{2}{*}{ Decision in 2013} & 0.076 & -0.061 & -0.057 & -0.048 & -0.008 & 0.160 & -0.176 \\
\hline & $(0.131)$ & $(0.131)$ & $(0.131)$ & $(0.131)$ & $(0.148)$ & $(0.112)$ & $(0.144)$ \\
\hline \multirow[t]{2}{*}{ Judicial Department N1 } & $-0.707^{* *}$ & $-0.592^{*}$ & $-0.592^{*}$ & $-0.602^{*}$ & -0.557 & 0.070 & \\
\hline & $(0.313)$ & $(0.325)$ & $(0.329)$ & $(0.331)$ & $(0.412)$ & $(0.330)$ & \\
\hline \multirow[t]{2}{*}{ Judicial Department N2 } & -0.191 & -0.078 & -0.080 & -0.100 & -0.059 & $0.531^{*}$ & \\
\hline & $(0.304)$ & $(0.317)$ & $(0.322)$ & $(0.323)$ & $(0.418)$ & $(0.322)$ & \\
\hline \multirow[t]{2}{*}{ Judicial Department N3 } & $0.506^{*}$ & 0.463 & 0.465 & 0.462 & 0.584 & 0.524 & \\
\hline & $(0.289)$ & $(0.296)$ & $(0.302)$ & $(0.301)$ & $(0.389)$ & $(0.358)$ & \\
\hline \multirow[t]{2}{*}{ Judicial Department N4 } & $-0.587^{*}$ & $-0.723^{* *}$ & $-0.734^{* *}$ & $-0.747^{* *}$ & $-0.697^{*}$ & -0.144 & \\
\hline & $(0.319)$ & $(0.322)$ & $(0.322)$ & $(0.323)$ & $(0.409)$ & $(0.325)$ & \\
\hline \multirow[t]{2}{*}{ Judicial Department N6 } & 0.210 & 0.143 & 0.141 & 0.135 & 0.062 & -0.107 & \\
\hline & $(0.314)$ & $(0.320)$ & $(0.324)$ & $(0.324)$ & $(0.423)$ & $(0.367)$ & \\
\hline \multirow[t]{2}{*}{ Judicial Department N7 } & $-1.107^{* * *}$ & $-1.083^{* * *}$ & $-1.087^{* * *}$ & $-1.084^{* * *}$ & $-1.035^{* *}$ & -0.230 & \\
\hline & $(0.330)$ & $(0.333)$ & $(0.336)$ & $(0.337)$ & $(0.409)$ & $(0.331)$ & \\
\hline \multirow[t]{2}{*}{ RHE appeal } & $-0.260^{*}$ & $-0.371^{* *}$ & $-0.370^{* *}$ & $-0.368^{* *}$ & $-0.292^{*}$ & $-0.602^{* * *}$ & $-0.465^{* * *}$ \\
\hline & $(0.145)$ & $(0.151)$ & $(0.151)$ & $(0.151)$ & $(0.176)$ & $(0.148)$ & $(0.161)$ \\
\hline \multirow[t]{2}{*}{ Seniority } & -0.00001 & -0.00002 & -0.00002 & -0.00002 & 0.0002 & -0.0001 & -0.012 \\
\hline & $(0.007)$ & $(0.007)$ & $(0.007)$ & $(0.007)$ & $(0.008)$ & $(0.009)$ & $(0.010)$ \\
\hline Total times at Justices offices & & $0.083^{* * *}$ & $0.083^{* * *}$ & $0.084^{* * *}$ & $0.078^{* * *}$ & -0.018 & 0.028 \\
\hline & & $(0.016)$ & $(0.016)$ & $(0.016)$ & $(0.019)$ & $(0.015)$ & $(0.020)$ \\
\hline Separate opinion & & & -0.191 & -0.186 & -0.176 & -0.268 & -0.046 \\
\hline & & & $(0.214)$ & $(0.215)$ & $(0.231)$ & $(0.263)$ & $(0.238)$ \\
\hline Supreme Court pres in majority & & & & 0.159 & 0.115 & 0.239 & $0.360^{* *}$ \\
\hline & & & & $(0.186)$ & $(0.210)$ & $(0.152)$ & $(0.145)$ \\
\hline Nat'l government as party & & & & & -0.009 & $-0.396^{* * *}$ & $-0.357^{* *}$ \\
\hline & & & & & $(0.185)$ & $(0.150)$ & $(0.157)$ \\
\hline Additional dissents & & & & & & $3.838^{* * *}$ & $3.573^{* * *}$ \\
\hline & & & & & & $(0.157)$ & $(0.134)$ \\
\hline Rapporteur Lorenzetti & & & & & & & -0.586 \\
\hline & & & & & & & $(0.461)$ \\
\hline Rapporteur Maqueda & & & & & & & -0.690 \\
\hline & & & & & & & $(0.513)$ \\
\hline Rapporteur Petracchi & & & & & & & -0.388 \\
\hline & & & & & & & $(0.455)$ \\
\hline Rapporteur Fayt & & & & & & & -0.300 \\
\hline & & & & & & & $(0.481)$ \\
\hline Rapporteur Zaffaroni & & & & & & & -0.389 \\
\hline & & & & & & & $(0.454)$ \\
\hline Rapporteur Highton & & & & & & & -0.106 \\
\hline & & & & & & & $(0.464)$ \\
\hline Constant & $-3.303^{* * *}$ & $-3.979^{* * *}$ & $-3.939^{* * *}$ & $-4.068^{* * *}$ & $-3.993^{* * *}$ & $-5.242^{* * *}$ & $-4.237^{* * *}$ \\
\hline & $(0.339)$ & $(0.390)$ & $(0.385)$ & $(0.430)$ & $(0.536)$ & $(0.478)$ & $(0.583)$ \\
\hline Observations & 11,102 & 11,102 & 11,102 & 11,102 & 8827 & 8827 & 6489 \\
\hline $\mathrm{R}^{2}$ & 0.166 & 0.179 & 0.180 & 0.180 & 0.173 & 0.406 & 0.384 \\
\hline chi $^{2}$ & $561.161^{* * *}$ & $605.961^{* * *}$ & $607.297^{* * * *}$ & $608.661^{* * * *}$ & $469.176^{* * * *}$ & $1139.560^{* * *}$ & $750.381^{* * *}$ \\
\hline & $(\mathrm{df}=14)$ & $(\mathrm{df}=15)$ & $(\mathrm{df}=16)$ & $(\mathrm{df}=17)$ & $(\mathrm{df}=18)$ & $(\mathrm{df}=19)$ & $(\mathrm{df}=19)$ \\
\hline
\end{tabular}

Note: ${ }^{*} \mathrm{p}<0.1 ;{ }^{* *} \mathrm{p}<0.05 ;{ }^{* * *} \mathrm{p}<0.01$.

carrying separate concurring opinions failed to show any statistically significant difference in the likelihood of dissent. In contrast, decisions carrying an additional dissent were positively associated with the probability of dissent ( $\mathrm{p}$-value $<0.01$ ). When the national government is a party the probability of dissent was smaller in two specifications. Finally, the variable controlling for the rapporteur of the case failed to show any statistically significant effect on dissent probability.

Unobserved judicial characteristics could be affecting our results. For instance, as Arbitrariedad is a Supreme Court-made doctrine, a particular judicial taste for Arbitrariedad could be driving the results. To account for this possibility, we rerun our regressions including fixed judicial effects. ${ }^{41}$ The results are presented in Table 5. The regression results are generally the same and consistent with previous interpretation. Arbitrariedad decisions are more

\footnotetext{
41 These regressions also have clustered standard errors. Using judge fixed effects in a logit model is problematic because of the incidental parameters problem (Wooldridge, 2010). The different models suggested by Wooldridge (2010) to address the incidental parameters problem produce similar results. Therefore, we
} have opted for reporting Table 5 . 
Table 5

Binomial logit regression results, Justices fixed effects.

\begin{tabular}{|c|c|c|c|c|c|c|}
\hline & \multicolumn{6}{|c|}{ Dependent variable: } \\
\hline & \multicolumn{6}{|c|}{ Dissent or partial dissent $=1$} \\
\hline & (1) & (2) & (3) & (4) & (5) & $(6)$ \\
\hline \multirow[t]{2}{*}{ Argibay } & $1.061^{* * *}$ & $1.073^{* * *}$ & $1.074^{* * *}$ & $1.074^{* * *}$ & $1.124^{* * *}$ & $1.523^{* * *}$ \\
\hline & $(0.134)$ & $(0.134)$ & $(0.134)$ & $(0.134)$ & $(0.156)$ & $(0.206)$ \\
\hline \multirow[t]{2}{*}{ Fayt } & $-1.588^{* * *}$ & $-1.597^{* * *}$ & $-1.597^{* * *}$ & $-1.598^{* * *}$ & $-1.591^{* * *}$ & $-1.891^{* * *}$ \\
\hline & $(0.271)$ & $(0.272)$ & $(0.273)$ & $(0.273)$ & $(0.313)$ & $(0.360)$ \\
\hline \multirow[t]{2}{*}{ Lorenzetti } & $-1.588^{* * *}$ & $-1.597^{* * *}$ & $-1.597^{* * *}$ & $-1.598^{* * *}$ & $-1.516^{* * *}$ & $-1.808^{* * *}$ \\
\hline & $(0.269)$ & $(0.270)$ & $(0.270)$ & $(0.270)$ & $(0.295)$ & $(0.343)$ \\
\hline \multirow[t]{2}{*}{ Maqueda } & $-0.936^{* * *}$ & $-0.943^{* * *}$ & $-0.943^{* * *}$ & $-0.943^{* * *}$ & $-0.876^{* * *}$ & $-1.081^{* * *}$ \\
\hline & $(0.199)$ & $(0.201)$ & $(0.201)$ & $(0.201)$ & $(0.219)$ & $(0.267)$ \\
\hline \multirow[t]{2}{*}{ Petracchi } & -0.058 & -0.059 & -0.059 & -0.059 & -0.000 & 0.000 \\
\hline & $(0.152)$ & $(0.153)$ & $(0.153)$ & $(0.153)$ & $(0.173)$ & $(0.225)$ \\
\hline \multirow[t]{2}{*}{ Zaffaroni } & -0.219 & -0.221 & -0.221 & -0.221 & -0.117 & -0.152 \\
\hline & $(0.160)$ & $(0.161)$ & $(0.161)$ & $(0.161)$ & $(0.171)$ & $(0.222)$ \\
\hline \multirow[t]{2}{*}{ Arbitrariedad } & $0.984^{* * *}$ & $1.038^{* * *}$ & $1.016^{* * *}$ & $1.010^{* * *}$ & $0.954^{* * *}$ & $1.083^{* * *}$ \\
\hline & $(0.156)$ & $(0.157)$ & $(0.159)$ & $(0.158)$ & $(0.178)$ & $(0.154)$ \\
\hline \multirow[t]{2}{*}{ Article 280} & $-1.346^{* * *}$ & $-0.994^{* * *}$ & $-1.026^{* * *}$ & $-0.983^{* * *}$ & $-1.095^{* * *}$ & -0.449 \\
\hline & $(0.313)$ & $(0.336)$ & $(0.337)$ & $(0.346)$ & $(0.416)$ & $(0.287)$ \\
\hline \multirow[t]{2}{*}{ Reference to Procurador General } & $-0.837^{* * *}$ & $-0.926^{* * *}$ & $-0.933^{* * *}$ & $-0.928^{* * *}$ & $-1.056^{* * *}$ & $-0.521^{* * *}$ \\
\hline & $(0.214)$ & $(0.206)$ & $(0.206)$ & $(0.207)$ & $(0.250)$ & $(0.185)$ \\
\hline \multirow[t]{2}{*}{ Reference to previous decision } & $-0.294^{*}$ & 0.062 & 0.053 & 0.048 & 0.072 & 0.075 \\
\hline & $(0.169)$ & $(0.181)$ & $(0.181)$ & $(0.181)$ & $(0.216)$ & $(0.170)$ \\
\hline \multirow[t]{2}{*}{ Decision in 2013} & 0.077 & -0.061 & -0.056 & -0.048 & -0.007 & 0.160 \\
\hline & $(0.132)$ & $(0.132)$ & $(0.132)$ & $(0.132)$ & $(0.148)$ & $(0.111)$ \\
\hline \multirow[t]{2}{*}{ Judicial Department N1 } & $-0.709^{* *}$ & $-0.595^{*}$ & $-0.595^{*}$ & $-0.605^{*}$ & -0.558 & 0.059 \\
\hline & $(0.314)$ & $(0.326)$ & $(0.331)$ & $(0.332)$ & $(0.413)$ & $(0.332)$ \\
\hline \multirow[t]{2}{*}{ Judicial Department N2 } & -0.193 & -0.079 & -0.080 & -0.101 & -0.059 & 0.519 \\
\hline & $(0.305)$ & $(0.319)$ & $(0.324)$ & $(0.325)$ & $(0.419)$ & $(0.325)$ \\
\hline \multirow[t]{2}{*}{ Judicial Department N3 } & $0.510^{*}$ & 0.466 & 0.469 & 0.465 & 0.589 & 0.537 \\
\hline & $(0.290)$ & $(0.298)$ & $(0.304)$ & $(0.303)$ & $(0.390)$ & $(0.362)$ \\
\hline \multirow[t]{2}{*}{ Judicial Department N4 } & $-0.588^{*}$ & $-0.726^{* *}$ & $-0.737^{* *}$ & $-0.750^{* *}$ & $-0.699 *$ & -0.159 \\
\hline & $(0.320)$ & $(0.323)$ & $(0.323)$ & $(0.324)$ & $(0.410)$ & $(0.329)$ \\
\hline \multirow[t]{2}{*}{ Judicial Department N6 } & 0.212 & 0.143 & 0.141 & 0.135 & 0.062 & -0.109 \\
\hline & $(0.316)$ & $(0.322)$ & $(0.326)$ & $(0.327)$ & $(0.425)$ & $(0.370)$ \\
\hline Judicial Department N7 & $-1.109^{* * *}$ & $-1.085^{* * *}$ & $-1.089^{* * * *}$ & $-1.086^{* * *}$ & $-1.036^{* *}$ & -0.240 \\
\hline & $(0.331)$ & $(0.334)$ & $(0.337)$ & $(0.338)$ & $(0.409)$ & $(0.334)$ \\
\hline RHE appeal & $-0.261^{*}$ & $-0.372^{* *}$ & $-0.371^{* *}$ & $-0.370^{* *}$ & $-0.293^{*}$ & $-0.596^{* * *}$ \\
\hline & $(0.145)$ & $(0.151)$ & $(0.152)$ & $(0.152)$ & $(0.177)$ & $(0.149)$ \\
\hline Total times at Justices offices & & $0.084^{* * *}$ & $0.084^{* * * *}$ & $0.084^{* * * *}$ & $0.078^{* * *}$ & -0.018 \\
\hline & & $(0.016)$ & $(0.016)$ & $(0.016)$ & $(0.020)$ & $(0.016)$ \\
\hline Separate opinion & & & -0.192 & -0.187 & -0.177 & -0.258 \\
\hline & & & $(0.215)$ & $(0.216)$ & $(0.232)$ & $(0.262)$ \\
\hline Supreme Court pres in majority & & & & 0.160 & 0.116 & 0.248 \\
\hline & & & & $(0.187)$ & $(0.210)$ & $(0.154)$ \\
\hline Nat'l government as party & & & & & -0.009 & $-0.402^{* * *}$ \\
\hline & & & & & $(0.186)$ & $(0.152)$ \\
\hline Additional dissents & & & & & & $3.885^{* * *}$ \\
\hline & & & & & & $(0.159)$ \\
\hline Constant & $-2.384^{* * *}$ & $-3.057^{* * *}$ & $-3.017^{* * *}$ & $-3.147^{* * *}$ & $-3.114^{* * *}$ & $-4.166^{* * *}$ \\
\hline & $(0.310)$ & $(0.374)$ & $(0.371)$ & $(0.400)$ & $(0.499)$ & $(0.442)$ \\
\hline Observations & 11,102 & 11,102 & 11,102 & 11,102 & 8827 & 8827 \\
\hline $\mathrm{R}^{2}$ & 0.183 & 0.196 & 0.196 & 0.197 & 0.189 & 0.423 \\
\hline $\mathrm{chi}^{2}$ & $618.981^{* * *}$ & $664.048^{* * *}$ & $665.393^{* * *}$ & $666.773^{* * *}$ & $512.444^{* * *}$ & $1189.593^{* * *}$ \\
\hline & $(\mathrm{df}=18)$ & $(\mathrm{df}=19)$ & $(\mathrm{df}=20)$ & $(\mathrm{df}=21)$ & $(\mathrm{df}=22)$ & $(\mathrm{df}=23)$ \\
\hline
\end{tabular}

Note: ${ }^{*} \mathrm{p}<0.1 ;{ }^{* *} \mathrm{p}<0.05 ;{ }^{* * *} \mathrm{p}<0.01$

likely to carry a dissenting opinion than REF decisions in all specifications ( $\mathrm{p}$-value < 0.01). In turn, Article 280 decisions are associated with a lower probability of dissent ( $\mathrm{p}$-value $<0.01$, in all but one specification).$^{42}$

We also run the same exercise at decision level, rather than with individual votes. This robustness test addresses concerns about the independence of individual votes and the dynamics of aggregation of preferences at the court level. The results we derived with

42 As compared to Justice Highton, Justice Argibay is more likely to dissent ( $p$-value $<0.01$ ), while Justices Fayt, Lorenzetti and Maqueda are less likely to dissent (pvalues $<0.01$ ). No statistically significant difference is detected for Justices Petracchi and Zaffaroni. previous approaches are replicated at decision level as we can see from Table 6. In particular, the empirical observations concerning Arbitrariedad and Article 280 are unchanged.

The results presented in Tables 4-6 show that, having REF as the benchmark, dissent is more likely for Arbitrariedad and less likely for Article 280. There are different interpretations for these results as we suggested that $R E F$ cases are, on average, more important than Arbitrariedad ones, and that each of them is, in turn, more important than Article 280 appeals. ${ }^{43}$

${ }^{43}$ Alternative specifications have been studied. One alternative specification is to
define the dependent variable as "1" if a dissenting vote, a partially dissenting vote or no vote occur and " 0 " otherwise (including concurring vote). A second alterna- 
Table 6

Binomial logit regression results. Decision level.

\begin{tabular}{|c|c|c|c|c|c|c|c|}
\hline & Dependent & & & & & & \\
\hline & Dissent or $\mathrm{p}$ & dissent $=1$ & & & & & \\
\hline & (1) & (2) & (3) & (4) & $(5)$ & (6) & (7) \\
\hline Arbitrariedad & $1.772^{* * *}$ & $1.827^{* * *}$ & $1.785^{* * *}$ & $1.773^{* * *}$ & $1.611^{* * *}$ & $1.882^{* * *}$ & $1.486^{* * *}$ \\
\hline & $(0.182)$ & $(0.185)$ & $(0.186)$ & $(0.187)$ & $(0.194)$ & $(0.239)$ & $(0.292)$ \\
\hline Article 280 & $-1.128^{* * *}$ & $-0.898^{* * *}$ & $-0.957^{* * *}$ & $-0.849^{* * *}$ & $-0.959^{* * *}$ & -0.598 & $-0.922^{* *}$ \\
\hline & $(0.306)$ & $(0.314)$ & $(0.316)$ & $(0.317)$ & $(0.319)$ & $(0.415)$ & $(0.441)$ \\
\hline Reference to Procurador General & $-0.957^{* * *}$ & $-1.071^{* * *}$ & $-1.080^{* * *}$ & $-1.075^{* * *}$ & $-1.062^{* * *}$ & $-0.693^{* *}$ & $-1.208^{* * *}$ \\
\hline & $(0.234)$ & $(0.235)$ & $(0.235)$ & $(0.236)$ & $(0.234)$ & $(0.301)$ & $(0.341)$ \\
\hline Reference to previous decision & 0.014 & 0.284 & 0.271 & 0.253 & 0.244 & 0.311 & -0.130 \\
\hline & $(0.200)$ & $(0.213)$ & $(0.214)$ & $(0.214)$ & $(0.213)$ & $(0.289)$ & $(0.299)$ \\
\hline Decision in 2013 & 0.077 & -0.014 & -0.007 & 0.022 & 0.105 & 0.195 & -0.421 \\
\hline & $(0.160)$ & $(0.164)$ & $(0.164)$ & $(0.165)$ & $(0.168)$ & $(0.209)$ & $(0.259)$ \\
\hline Judicial Department N1 & $-0.696^{*}$ & -0.599 & -0.603 & -0.622 & -0.498 & -0.405 & \\
\hline & $(0.395)$ & $(0.398)$ & $(0.397)$ & $(0.397)$ & $(0.403)$ & $(0.562)$ & \\
\hline Judicial Department N2 & 0.162 & 0.246 & 0.253 & 0.210 & 0.175 & 0.220 & \\
\hline & $(0.381)$ & $(0.383)$ & $(0.383)$ & $(0.384)$ & $(0.388)$ & $(0.546)$ & \\
\hline Judicial Department N3 & $0.992^{* *}$ & $0.987^{* *}$ & $0.993^{* *}$ & $1.011^{* * * *}$ & $0.983^{* *}$ & $1.178^{* *}$ & \\
\hline & $(0.387)$ & $(0.390)$ & $(0.389)$ & $(0.390)$ & $(0.394)$ & $(0.548)$ & \\
\hline Judicial Department N4 & $-0.768^{* *}$ & $-0.883^{* *}$ & $-0.902^{* *}$ & $-0.935^{* *}$ & $-0.839^{* *}$ & -0.823 & \\
\hline & $(0.382)$ & $(0.386)$ & $(0.386)$ & $(0.387)$ & $(0.394)$ & $(0.581)$ & \\
\hline Judicial Department N6 & 0.068 & 0.019 & 0.018 & 0.004 & 0.011 & -0.259 & \\
\hline & $(0.408)$ & $(0.410)$ & $(0.410)$ & $(0.410)$ & $(0.411)$ & $(0.606)$ & \\
\hline Judicial Department N7 & $-1.237^{* * *}$ & $-1.213^{* * *}$ & $-1.215^{* * *}$ & $-1.201^{* * *}$ & $-1.086^{* * *}$ & -0.767 & \\
\hline & $(0.390)$ & $(0.391)$ & $(0.391)$ & $(0.392)$ & $(0.396)$ & $(0.559)$ & \\
\hline RHE appeal & $-0.578^{* * *}$ & $-0.650^{* * *}$ & $-0.648^{* * *}$ & $-0.635^{* * *}$ & $-0.694^{* * *}$ & $-0.682^{* * *}$ & $-0.573^{* *}$ \\
\hline & $(0.171)$ & $(0.174)$ & $(0.174)$ & $(0.174)$ & $(0.175)$ & $(0.221)$ & $(0.263)$ \\
\hline Total times at Justices offices & & $0.066^{* * *}$ & $0.065^{* * *}$ & $0.067^{* * *}$ & $0.059^{* * *}$ & -0.036 & 0.031 \\
\hline & & $(0.019)$ & $(0.019)$ & $(0.019)$ & $(0.019)$ & $(0.027)$ & $(0.036)$ \\
\hline Separate opinion & & & -0.365 & -0.351 & -0.353 & -0.369 & 0.125 \\
\hline & & & $(0.244)$ & $(0.245)$ & $(0.247)$ & $(0.318)$ & $(0.370)$ \\
\hline Supreme Court pres in majority & & & & $0.418^{* *}$ & $0.411^{* *}$ & $0.855^{* * *}$ & $0.910^{* * * *}$ \\
\hline & & & & $(0.202)$ & $(0.203)$ & $(0.293)$ & $(0.331)$ \\
\hline Nat'l government as party & & & & & -0.301 & $-0.666^{* *}$ & $-0.647^{* *}$ \\
\hline & & & & & $(0.196)$ & $(0.265)$ & $(0.276)$ \\
\hline Additional dissents & & & & & & 13.799 & 13.294 \\
\hline & & & & & & $(24.247)$ & $(22.618)$ \\
\hline Rapporteur Lorenzetti & & & & & & & $-1.742^{* *}$ \\
\hline & & & & & & & $(0.814)$ \\
\hline Rapporteur Maqueda & & & & & & & $-1.619^{*}$ \\
\hline & & & & & & & $(0.838)$ \\
\hline Rapporteur Petracchi & & & & & & & -1.230 \\
\hline & & & & & & & $(0.752)$ \\
\hline Rapporteur Fayt & & & & & & & $-2.103^{*}$ \\
\hline & & & & & & & $(1.264)$ \\
\hline Rapporteur Zaffaroni & & & & & & & -0.652 \\
\hline & & & & & & & $(0.763)$ \\
\hline Rapporteur Highton & & & & & & & -1.112 \\
\hline & & & & & & & $(0.764)$ \\
\hline Constant & $-1.095^{* * *}$ & $-1.606^{* * *}$ & $-1.532^{* * *}$ & $-1.885^{* * *}$ & $-1.634^{* * *}$ & $-2.348^{* * *}$ & -1.157 \\
\hline & $(0.370)$ & $(0.402)$ & $(0.406)$ & $(0.441)$ & $(0.449)$ & $(0.634)$ & $(0.861)$ \\
\hline Observations & 1586 & 1586 & 1586 & 1586 & 1486 & 1486 & 1113 \\
\hline $\mathrm{R}^{2}$ & 0.302 & 0.312 & 0.314 & 0.317 & 0.319 & 0.606 & 0.578 \\
\hline $\mathrm{chi}^{2}$ & $336.227^{* * *}$ & $348.489^{* * *}$ & $350.840^{* * * *}$ & $355.296^{* * *}$ & $342.877^{* * * *}$ & $736.692^{* * *}$ & $485.843^{* * *}$ \\
\hline & $(\mathrm{df}=12)$ & $(\mathrm{df}=13)$ & $(\mathrm{df}=14)$ & $(\mathrm{df}=15)$ & $(\mathrm{df}=16)$ & $(\mathrm{df}=17)$ & $(\mathrm{df}=17)$ \\
\hline
\end{tabular}

Note: ${ }^{*} \mathrm{p}<0.1 ;{ }^{* *} \mathrm{p}<0.05 ;{ }^{* * *} \mathrm{p}<0.01$

tive specification is to code "1" if not voting with the majority (including concurs) while " 0 " otherwise. The results are available upon request. There are two significant changes. First, Arbitrariedad has the same positive sign, but is not statistically significant. Second, Article 280 has now a positive impact (i.e., by comparison with REF) and is statistically significant in all specifications. The former effect is likely dependent on lumping together concurring and dissenting opinions. Separate concurring opinions in Arbitrariedad and REF are reasoned (costlier) opinions. Given the lesser importance of Arbitrariedad cases, it is consistent with the theory to have fewer separate concurring opinions in these cases (relative to REF ones), which may explain the lack of significance in these regressions. The latter effect is directly dependent on including no votes in the dependent variable, as the Supreme Court has a practice to stop file circulation when a majority is reached in cases of appeals dismissals, and only those Justices who have seen the file typically vote on a case. Therefore, the specifications discussed in the text are more robust to judicial motivations.
One possible explanation is that the net benefits of dissent are not sufficient to induce a higher likelihood of dissent in more important cases (i.e., REF versus Arbitrariedad appeals). To further investigate why dissents are more likely in Arbitrariedad decisions, we compared the different types of dissents Justices voiced in $R E F$ and Arbitrariedad decisions. Of the 218 Arbitrariedad dissenting votes, only 10 (about 5\%) came in the form of reasoned opinions. This figure is relatively much smaller than the 38 votes out of 210 REF dissents ( $18 \%$ ) that came in the form of reasoned opinions. ${ }^{44}$

\footnotetext{
44 In unreported results, we ran several multinomial regression models to test the effects of the type of decision on the type of dissents. The results obtained in those regressions confirm that $R E F$ decisions are associated to a smaller probability of
} 
Summary statistics, number of words in majority opinion.

\begin{tabular}{|c|c|c|c|c|c|c|}
\hline Dissent & Reference & Mean & Median & 25th quantile & 75th quantile & Standard Deviation \\
\hline Boilerplate dissent & No & 895.17 & 822 & 609 & 1054 & 480.77 \\
\hline No dissent & No & $1,359.82$ & 885.5 & 505.5 & $1,631.5$ & $1,343.77$ \\
\hline Reasoned dissent & No & $4,147.95$ & 1763 & $1,295.5$ & $4,202.5$ & $5,021.14$ \\
\hline Reference dissent & No & $1,832.62$ & $1,733.5$ & $1,484.25$ & $2,057.5$ & 791.57 \\
\hline Boilerplate dissent & Yes & 149.06 & 159 & 98 & 175 & 66.52 \\
\hline No dissent & Yes & 158.8 & 119 & 89 & 189 & 134.68 \\
\hline Reasoned dissent & Yes & 124.67 & 85.5 & 75.75 & 107.5 & 127.84 \\
\hline Reference dissent & Yes & 180.41 & 118.5 & 105.25 & 132 & 311.71 \\
\hline
\end{tabular}

These numbers suggest that the actual average cost of casting a dissenting vote, and of responding to a dissenting vote, is larger in $R E F$ than in Arbitrariedad decisions, and higher incidences of dissent seem to be related to lower costs of dissenting. ${ }^{45}$

An alternative explanation is based on court dynamics rather than individual behavior, but with a focus on the benefit side. Due to the importance of $R E F$, the Justices make an effort to compromise for the sake of legitimacy and therefore we observe less dissent. However, for Arbitrariedad, given its comparatively insignificant legal relevance, efforts to compromise are diminished and we observe more dissent.

Yet another possible interpretation is that the higher rates of dissents in Arbitrariedad reflect the nature of the appeal (for example, some could argue there is a lower degree of certainty about the right legal answer to issues in Arbitrariedad than in REF). Seemingly, however, the nature of the appeal is captured by the origin of appeal (direct appeal - RHE), area of the law (controlled by Judicial Department N1 to N7), and references to previous cases and opinions by the Procurador General. Therefore, an interpretation that argues that dissents are somehow driven by the nature of the law is empirically problematic and can be plausibly rejected given the control variables used in columns (1)-(7) on Tables 4-6. ${ }^{46}$

\section{Further results}

In order to assess whether different dissents entail different cost levels, we turn to the reactions of the majority produced by different types of dissenting opinions. To study the different cost levels, we focused on Supreme Court decisions as our unit of observation. We excluded from our database cases decided on Article 280 grounds, as they are run-of-the-mill decisions with little to no length variation. ${ }^{47}$ Table 7 shows summary statistics for the number of words in the majority opinion. The table shows two distinct types of scenarios according to whether the majority opinion issued its decision based on a reference to a previous decision or not. The former decisions are on average much shorter (158 words on average), regardless of whether or not a dissent was present. The latter decisions are much longer, on average (1637 words), especially when there is a reasoned dissent. Focusing on decisions with no reference, decisions carrying reasoned dissents are on average 4148 words long, more than three times as many words as the average decision carrying no dissent. At the same time, decisions with

boilerplate dissents -relative to reasoned dissents- ( $\mathrm{p}$-value $<0.01$ in all regression specifications).

${ }^{45}$ This implies that about $82 \%$ of dissents in REF and 95\% in Arbitrariedad decisions do not come in the form of reasoned opinions. This shows that in both types of decisions there are ways to dissent without incurring substantial costs. However, on average, REF decisions are associated with less boilerplate dissents than Arbitrariedad, thus reflecting the legal importance of REF over Arbitrariedad cases.

${ }^{46}$ Further skepticism about this explanation is supported by our analysis in the Appendix.

47 In the past, these decisions were issued by imprinting a large stamp on a piece of paper. While the technology has been upgraded, the practice remains largely the same. boilerplate dissents tend to be much shorter, containing on average 895 words.

To test these results in a multivariate setting, we performed a series of multiple least square regressions. Our dependent variable is the $\log$ of the total number of words in the majority opinion. ${ }^{48}$ Our key independent variable is dissent type, a categorical variable taking one of four values: no dissent, boilerplate dissent (a boilerplate decision; typically based on Article 280 or Acordada 4/2007 grounds), reference dissent (a dissenting opinion which merely refers to one or more previous opinions), or reasoned opinion. We included several control variables to take into account the Supreme Court's institutional setting and case characteristics. Given the Supreme Court's practice of relying on previous decisions, we included the variable reference to control for the decisions where the majority grounds its opinion on a previous decision or on the opinion of the Procurador General. Initial drafts of decisions are typically included in the memos written by the thematically specialized Judicial Department. Hence, we included the variable Judicial Department (with seven levels, one per Judicial Department) to control for differences in writing style within each office. We also included a dummy variable for decisions issued in 2013 -decision in 2013 - to capture any possible caseload effects.

Differences in jurisdictional source were captured by a categorical variable representing four levels (Federal, Fed/Nat, Local and National). To account for possible differences between appeals granted by the lower court and direct appeals, we included a dummy taking value "1" for RHE and "0" for REX. Because cases of greater importance may generate longer majority opinion, we introduced a dummy variable taking value "1" for cases raising federal/ constitutional questions $(R E F)$ and taking value " 0 " for cases decided on due process grounds (Arbitrariedad). For comparison purposes, we also included a dummy variable (dissent) taking value " 1 " if a decision included a dissent or partial dissent and " 0 " otherwise.

Separate concurring opinions may also have an effect on the majority, as the latter seems to take the former into account. Hence, we incorporate a dummy variable called separate opinion. More complex cases may require more study at each Justice's office or at each Judicial Department and may generate longer opinions. Hence, we included a variable capturing the number of times an appeal file circulated through a Justice's offices - total times at Justices offices. Finally, opinions with more dissenters may require more effort from the majority. To account for this, we incorporated a dummy variable ( 2 or more dissenters) to the regressions.

Table 8 reports the results. While dissent has a statistically significant effect on majority opinion length, most of the effect seems to be attributed to opinions with reasoned dissent. As compared with decisions containing boilerplate dissents, decisions with reasoned dissents tend to be longer, a result that is statistically significant ( $p$-value $<0.05$ ). This result is not only statistically sig-

\footnotetext{
48 The total number of words includes footnotes, though footnotes are seldom used in Supreme Court's opinions.
} 
Table 8

Regression results, robust standard errors.

\begin{tabular}{|c|c|c|c|c|c|}
\hline & \multicolumn{5}{|c|}{ Dependent variable: } \\
\hline & \multicolumn{5}{|c|}{ Log number of words in majority opinion } \\
\hline & (1) & $(2)$ & (3) & $(4)$ & (5) \\
\hline Dissent & $\begin{array}{l}0.115^{* *} \\
(0.045)\end{array}$ & & & & \\
\hline Reference & $\begin{array}{l}-2.063^{* * *} \\
(0.087)\end{array}$ & $\begin{array}{l}-2.020^{* * *} \\
(0.080)\end{array}$ & $\begin{array}{l}-2.071^{* * *} \\
(0.081)\end{array}$ & $\begin{array}{l}-2.054^{* * *} \\
(0.077)\end{array}$ & $\begin{array}{l}-2.052^{* * *} \\
(0.076)\end{array}$ \\
\hline Judicial Department N2 & $\begin{array}{l}0.234^{* * *} \\
(0.069)\end{array}$ & $\begin{array}{l}0.254^{* * *} \\
(0.070)\end{array}$ & $\begin{array}{l}0.228^{* * *} \\
(0.073)\end{array}$ & $\begin{array}{l}0.224^{* * *} \\
(0.072)\end{array}$ & $\begin{array}{l}0.225^{* * *} \\
(0.072)\end{array}$ \\
\hline Judicial Department N3 & $\begin{array}{l}-0.169 \\
(0.159)\end{array}$ & $\begin{array}{l}-0.158 \\
(0.147)\end{array}$ & $\begin{array}{l}-0.136 \\
(0.190)\end{array}$ & $\begin{array}{l}-0.191 \\
(0.180)\end{array}$ & $\begin{array}{l}-0.187 \\
(0.180)\end{array}$ \\
\hline Judicial Department N4 & $\begin{array}{l}-0.116^{*} \\
(0.064)\end{array}$ & $\begin{array}{l}-0.121^{*} \\
(0.064)\end{array}$ & $\begin{array}{l}-0.073 \\
(0.071)\end{array}$ & $\begin{array}{l}-0.059 \\
(0.070)\end{array}$ & $\begin{array}{c}-0.057 \\
(0.070)\end{array}$ \\
\hline Judicial Department N5 & $\begin{array}{l}0.119 \\
(0.123)\end{array}$ & $\begin{array}{l}0.086 \\
(0.116)\end{array}$ & $\begin{array}{l}0.105 \\
(0.125)\end{array}$ & $\begin{array}{l}0.090 \\
(0.123)\end{array}$ & $\begin{array}{l}0.086 \\
(0.121)\end{array}$ \\
\hline Judicial Department N6 & $\begin{array}{l}0.069 \\
(0.099)\end{array}$ & $\begin{array}{l}0.066 \\
(0.099)\end{array}$ & $\begin{array}{l}0.095 \\
(0.102)\end{array}$ & $\begin{array}{l}0.090 \\
(0.099)\end{array}$ & $\begin{array}{l}0.080 \\
(0.099)\end{array}$ \\
\hline Judicial Department N7 & $\begin{array}{l}0.243^{* * *} \\
(0.066)\end{array}$ & $\begin{array}{l}0.239^{* * *} \\
(0.065)\end{array}$ & $\begin{array}{l}0.260^{* * *} \\
(0.069)\end{array}$ & $\begin{array}{l}0.266^{* * *} \\
(0.068)\end{array}$ & $\begin{array}{l}0.269^{* * *} \\
(0.067)\end{array}$ \\
\hline Decision in 2013 & $\begin{array}{l}0.127^{* * *} \\
(0.041)\end{array}$ & $\begin{array}{l}0.122^{* * *} \\
(0.040)\end{array}$ & $\begin{array}{l}0.144^{* * * *} \\
(0.039)\end{array}$ & $\begin{array}{l}0.131^{* * *} \\
(0.039)\end{array}$ & $\begin{array}{l}0.131^{* * *} \\
(0.039)\end{array}$ \\
\hline REF & $\begin{array}{l}0.142^{* * *} \\
(0.050)\end{array}$ & $\begin{array}{l}0.112^{* *} \\
(0.050)\end{array}$ & $\begin{array}{l}0.103^{* *} \\
(0.049)\end{array}$ & $\begin{array}{l}0.066 \\
(0.049)\end{array}$ & $\begin{array}{l}0.059 \\
(0.049)\end{array}$ \\
\hline RHE & $\begin{array}{l}0.010 \\
(0.039)\end{array}$ & $\begin{array}{l}0.006 \\
(0.038)\end{array}$ & $\begin{array}{l}0.031 \\
(0.039)\end{array}$ & $\begin{array}{l}0.037 \\
(0.039)\end{array}$ & $\begin{array}{l}0.031 \\
(0.039)\end{array}$ \\
\hline Fed/Nat jurisdiction & $\begin{array}{r}-0.070 \\
(0.137)\end{array}$ & $\begin{array}{l}-0.047 \\
(0.123)\end{array}$ & $\begin{array}{c}-0.034 \\
(0.173)\end{array}$ & $\begin{array}{l}0.019 \\
(0.164)\end{array}$ & $\begin{array}{l}0.023 \\
(0.164)\end{array}$ \\
\hline Local jurisdiction & $\begin{array}{l}0.088 \\
(0.094)\end{array}$ & $\begin{array}{l}0.093 \\
(0.092)\end{array}$ & $\begin{array}{l}0.118 \\
(0.096)\end{array}$ & $\begin{array}{l}0.083 \\
(0.092)\end{array}$ & $\begin{array}{l}0.085 \\
(0.092)\end{array}$ \\
\hline National jurisdiction & $\begin{array}{l}0.171^{* *} \\
(0.067)\end{array}$ & $\begin{array}{l}0.168^{* *} \\
(0.067)\end{array}$ & $\begin{array}{l}0.183^{* * *} \\
(0.066)\end{array}$ & $\begin{array}{l}0.159^{* *} \\
(0.064)\end{array}$ & $\begin{array}{l}0.173^{* * *} \\
(0.065)\end{array}$ \\
\hline No dissent & & $\begin{array}{c}-0.032 \\
(0.049)\end{array}$ & $\begin{array}{l}-0.024 \\
(0.052)\end{array}$ & $\begin{array}{r}-0.054 \\
(0.053)\end{array}$ & $\begin{array}{l}-0.009 \\
(0.057)\end{array}$ \\
\hline Reasoned dissent & & $\begin{array}{l}0.443^{* *} \\
(0.206)\end{array}$ & $\begin{array}{l}0.488^{* *} \\
(0.209)\end{array}$ & $\begin{array}{l}0.415^{* *} \\
(0.202)\end{array}$ & $\begin{array}{l}0.387^{* *} \\
(0.195)\end{array}$ \\
\hline Reference Dissent & & $\begin{array}{l}0.105 \\
(0.102)\end{array}$ & $\begin{array}{l}0.134 \\
(0.113)\end{array}$ & $\begin{array}{l}0.109 \\
(0.108)\end{array}$ & $\begin{array}{l}0.076 \\
(0.110)\end{array}$ \\
\hline Total times at Justices offices & & & $\begin{array}{l}-0.016^{* * *} \\
(0.005)\end{array}$ & $\begin{array}{l}-0.013^{* * *} \\
(0.005)\end{array}$ & $\begin{array}{l}-0.014^{* * *} \\
(0.005)\end{array}$ \\
\hline Separate opinion & & & & $\begin{array}{l}0.315^{* * *} \\
(0.062)\end{array}$ & $\begin{array}{l}0.312^{* * * *} \\
(0.062)\end{array}$ \\
\hline 2 or more dissenters & & & & & $\begin{array}{l}0.133^{*} \\
(0.079)\end{array}$ \\
\hline Constant & $\begin{array}{l}6.623^{* * *} \\
(0.114)\end{array}$ & $\begin{array}{l}6.646^{* * *} \\
(0.103)\end{array}$ & $\begin{array}{l}6.743^{* * *} \\
(0.114)\end{array}$ & $\begin{array}{l}6.733^{* * *} \\
(0.110)\end{array}$ & $\begin{array}{l}6.698^{* * *} \\
(0.110)\end{array}$ \\
\hline Observations & 1138 & 1137 & 1092 & 1092 & 1092 \\
\hline $\mathrm{R} 2$ & 0.629 & 0.633 & 0.638 & 0.651 & 0.652 \\
\hline Adjusted R2 & 0.624 & 0.628 & 0.632 & 0.645 & 0.646 \\
\hline
\end{tabular}

Note: ${ }^{*} \mathrm{p}<0.1 ;{ }^{* *} \mathrm{p}<0.05 ;{ }^{* * *} \mathrm{p}<0.01$. The number of observations is lower in regressions (3)-(5) due to missing observations. Robust standard errors in parentheses.

nificant, but also has practical implications. On average, a decision with a reasoned dissent tends to be $47 \%$ longer than a decision with a boilerplate dissent. In turn, we fail to find a statistically significant difference in majority opinion length between decisions carrying no dissent (or reference dissents) and those carrying a boilerplate dissent.

Decisions where the majority makes references to the opinion of the Procurador General or to previous decisions, variables that reflect the importance and complexity of the case, tend to be shorter than decisions without reference, a result which is highly statistically significant ( $p$-value $<0.01$ ). Also, decisions including at least one separate concurring opinion or decisions issued in 2013 tend to be longer on average (both results with a p-value $<0.01$ ). Decisions carrying an additional dissent tend to be longer ( $\mathrm{p}$-value $<0.1$ ). Accordingly, REF decisions tend to be longer, though this result is statistically significant in only 3 of our regression specifications ( $p$-value < 0.05). Finally, as circulation of an appeal file increases through judicial offices, majority opinions tend to be shorter ( $p$-value $<0.01$ ). The results presented in Table 6 are consistent with different types of dissents generating different levels of costs. Specifically, they show that only reasoned dissents generate the need for a stronger reaction by the majority, suggesting that some dissents (such as boilerplate) may carry much lower collegiality costs.

Taken together, our results strongly support the hypothesis that not all dissents carry equal weight. In fact, different types of dissent not only generate different response levels in the majority (in terms of the majority opinion extension), but also have a different likelihood of occurrence according to the importance of the case. Consistent with rational dissent theory, more important (REF) decisions are less likely to carry dissenting opinions. Meanwhile, reasoned dissents are more likely to occur in important cases (in line with the benefits side of rational dissent theory).

\section{Conclusion}

In this article we showed that the probability of dissent at the Supreme Court is affected by multiple factors. Specifically, and unlike previous empirical literature, we found that dissent is less common in complex and important cases. Within the institutional 
context, we showed that the probability of dissent is positively associated with less important decisions (i.e., based on Arbitrariedad grounds). In turn, Arbitrariedad dissents are more likely to be boilerplate than those appearing in more important decisions (i.e., REF ones). The boilerplate nature of Arbitrariedad dissents reduces the cost of producing a dissent. Further, more important REF cases (offering relatively more benefits to dissenters) are more likely to carry reasoned dissents.

In addition, we showed that different types of dissents generate different costs to the majority in terms of reacting to the dissenting opinion. Specifically, reasoned dissents are associated with longer majority opinions than those carrying boilerplate dissents, a statistically significant result at $5 \%$. Further, we failed to observe a statistically significant difference in majority opinion length in cases carrying no dissent relative to cases with boilerplate dissents.

These results highlight the importance of the types of dissent in terms of their propensity to impose additional costs on the majority. Boilerplate dissents likely entail lower collegiality costs because the majority is not required to exert additional effort to account for those dissents. In addition, these types of dissents are unlikely to ignite direct confrontations. Hence, we suggest that the lower cost of introducing dissents helps to explain their prominence in Arbitrariedad decisions. Also, the higher benefits of reasoned dissents help to explain the higher likelihood of dissent in more important appeals.

More generally, our results point to the fact that not all dissents carry equal weight, thus and complementing previous results by Epstein et al. (2011). The frequency of dissents is dependent also on the specific costs and benefits that each type of dissent introduces in a particular type of case. When dissent costs fall dramatically, as is often the case in Arbitrariedad cases, judicial dissent rate grows accordingly even if the benefits are also small, insignificant or even minimal. ${ }^{49}$ In turn, the higher probability of reasoned dissents (which are costly to produce and induce higher collegiality costs) in more important cases is consistent with the larger benefits and results previously obtained in the literature (Epstein et al., 2011). Further efforts by the literature to quantify the costs and benefits of dissents may offer a clearer window to the implicit calculations Justices make when deciding whether or not to dissent and what type of dissent to cast.

\section{Declaration of Competing Interest}

None.

\section{Appendix.}

\section{References to individual justices}

As Table A1 shows, all Justices have low levels of dissents. Nevertheless, Justice Argibay was clearly the Justice with most dissents as $11 \%$ of her votes were cast as dissenting opinions and $1 \%$ as a partial dissent. The Justice with the second highest dissenting rate, Highton de Nolasco, issued a dissenting or partially dissenting vote in just $5 \%$ of the decisions. Even though dissent rates are quite low, it does not translate into overwhelming levels of consensus. One of the reasons for this is that Justices very often decide not to cast a vote. For instance, Justice Fayt decided not to vote in $58 \%$ of the decisions in our sample.

\footnotetext{
${ }^{49}$ Moreover, if dissents do not become law in time (which is likely to be the case with Arbitrariedad), the reputation effect is much less relevant, thus reinforcing the view that costs are more relevant.
}

Table A1

Percentage of vote types by Justice.

\begin{tabular}{llllll}
\hline & With majority & Concurring & No vote & Dissent & Partial dissent \\
\hline Argibay $^{\mathrm{a}}$ & 0.35 & 0.03 & 0.5 & 0.11 & 0.01 \\
Fayt $^{\mathrm{b}}$ & 0.37 & 0.04 & 0.58 & 0.01 & 0 \\
Highton $^{\mathrm{c}}$ & 0.71 & 0.01 & 0.24 & 0.04 & 0.01 \\
Lorenzetti $^{\mathrm{d}}$ & 0.73 & 0.02 & 0.24 & 0.01 & 0 \\
Maqueda $^{\mathrm{C}}$ & 0.85 & 0.01 & 0.12 & 0.02 & 0 \\
Petracchi $^{\mathrm{f}}$ & 0.6 & 0.02 & 0.34 & 0.04 & 0 \\
Zaffaroni $^{\mathrm{g}}$ & 0.75 & 0.01 & 0.2 & 0.03 & 0.01 \\
\hline
\end{tabular}

a Justice Carmen Argibay (1939-2014) became a member of the Court in 2004 by choice of President Néstor Kirchner. She died in May 2014, while still a member of the Supreme Court.

b Justice Carlos Fayt (1918-2016) was nominated by President Raúl Alfonsín in 1983. He died in November 2016, while still a member of the Supreme Court.

c Justice Elena Highton de Nolasco (1942) was nominated by President Néstor Kirchner in 2004. She has been Vice-President of the Court since 2005.

d Justice Ricardo Lorenzetti (1955) was the President of the Court from 2007 to 2018. He was nominated to the Court by President Néstor Kirchner in 2004.

e Justice Juan Carlos Maqueda (1949) was nominated to the Court by President Eduardo Duhalde in 2002.

f Justice Enrique Petracchi (1935-2014) was nominated by President Raúl Alfonsín in 1983. He died in October 2014, while still a member of the Supreme Court.

g Justice Eugenio Zaffaroni (1940) was nominated by President Néstor Kirchner in 2003. He retired in 2015.

\section{Table A2}

Classification of type of Arbitrariedad as rule or standard.

\begin{tabular}{ll}
\hline Type of Arbitrariedad & Rule/Standard \\
\hline Not deciding issues brought up & Rule \\
Deciding issues not brought up & Rule \\
Taking the Judge the role of the legislator & Standard \\
Leave aside the applicable norm & Rule \\
Apply non-current law & Rule \\
Ground the decision in excessively lax terms & Standard \\
Leave aside decisive proofs & Standard \\
Invoke non-existent proofs & Rule \\
Contradict other elements of the case & Standard \\
Ground the decision in dogmatic claims & Standard \\
Excessive ritual rigor & Standard \\
Self-contradiction & Standard \\
Violation of a final decision & Standard \\
Omit the analysis of precedents & Standard \\
Lack of substantial coincidence on decision grounds & Standard \\
Other & Standard \\
\hline
\end{tabular}

\section{Alternative explanation}

It could be possible, though, that the legal theory explaining appeal admissibility (not the cost of dissent) justifies our Arbitrariedad results. In fact, some legal scholars and Supreme Court officials believe that Arbitrariedad admissibility is based on a standard while $R E F$ admissibility is based on a rule. ${ }^{50}$ As a result, different Justices may interpret differently whether the required Arbitrariedad standard has been met, making Arbitrariedad decisions more prone to dissents, regardless of costs considerations.

To explore this hypothesis, we reviewed each Arbitrariedad decision to identify the type of problem prompting each Justice in the majority to consider the arbitrariness of the lower court's decision. To that effect, we used a classification established by Carrió (1967), adding a couple of additional levels admitted by Supreme Court later on. Then, for each case we classified the Arbitrariedad criterion as a rule or a standard. To be precise, we classified an Arbitrariedad decision as being based on a rule if at least one rule criterion was used to justify the decision. Table A2 shows the types of Arbitrariedad and whether we classified them as a rule or a standard.

\footnotetext{
50 While the idea that the Supreme Court uses a standard for Arbitrariedad is conceivable, many of the Arbitrariedad decisions we reviewed failed to explicit the use
} of a standard. Further, there is no unique standard used by the court. 
Table A3

Number of Arbitrariedad decisions, by rule or standard.

\begin{tabular}{lll}
\hline & No reference & Reference \\
\hline Standard in Arbitrariedad & & \\
No dissent & 10 & 60 \\
Dissent & 8 & 40 \\
Rule in Arbitrariedad & 15 & 66 \\
No dissent & 14 & 101 \\
Dissent & & \\
\hline
\end{tabular}

We used this information to compare dissents in Arbitrariedad decisions based on whether the majority opinion made a reference ${ }^{51}$ and on whether at least one of the grounds for finding the lower court decision arbitrary was a rule. Table A3 presents the results.

\section{Appendix B. Supplementary data}

Supplementary material related to this article can be found, in the online version, at doi:https://doi.org/10.1016/j.irle.2020. 105909.

\section{References}

Amaral-Garcia, Sofia, Garoupa, Nuno, 2017. Judicial behavior and devolution at the Privy Council. Rev. Law Econ. 13 (3).

Benedetti, Miguel A., Saenz, Maria J., 2016. Las Audiencias Públicas de la Corte Suprema. Apertura y Límites de la Participación Ciudadana en la Justicia. Siglo Veintiuno Editores, Buenos Aires.

Gonzalez-Bertomeu, Juan, Dalla Pellegrina, Lucia, Garoupa, Nuno, 2017. Estimating judicial ideal points in Latin America: the case of Argentina. Rev. Law Econ. 13 (1).

Berzon, Marsha S., 2012. Dissent, "dissentals", and decision making. Calif. Law Rev. $100,1479-1492$

Brennan Jr., William J., 1985. In defense of dissents. Hastings Law J. 37, 427-438.

Carrió, Genaro R., 1967. El Recurso Extraordinario por Sentencia Arbitraria en la Jurisprudencia de la Corte Suprema. Editorial Abeledo-Perrot.

Edelman, Paul H., Klein, David E., Lindquist, Stephanie A., 2012. Consensus, disorder, and ideology on the Supreme Court. J. Empir. Leg. Stud. 9, 129-148.

Epstein, Lee, Segal, Jeffrey A., Spaeth, Harold J., 2001. The norm of consensus on the U.S. Supreme Court. Am. J. Pol. Sci. 45, 362-377.

Epstein, Lee, Landes, William M., Posner, Richard A., 2011. Why (and when) judges dissent: a theoretical and empirical analysis. J. Leg. Anal. 3, 101-137.

Epstein, Lee, Landes, William M., Posner, Richard A., 2013. The Behavior of Federal Judges. Harvard University Press.

Fischman, Joshua, 2011. Estimating preferences of circuit judges: a model of consensus voting. J. Law Econ. 54, 781-809.

Fon, Vincy, Parisi, Francesco, 2006. Judicial precedents in civil law systems: a dynamic analysis. Int. Rev. Law Econ. 26, 519-535.
Gerber, Scott D., Park, Keeok, 1997. The quixotic search for consensus on the U.S. Supreme Court: a cross-judicial empirical analysis of the Rehnquist court justices. Am. Polit. Sci. Rev. 91, 390-408.

Good, I.J., Tullock, Gordon, 1984. Judicial errors and a proposal for reform. J. Legal Stud. 13, 289-298.

Haire, Susan, Moyer, Laura, Treier, Shawn, 2013. Diversity, deliberations, and judicial opinion writing. J. Law Courts 1,303-330.

Harnay, Sophie, Marciano, Alain, 2003. Judicial conformity and dissidence: an economic analysis of judicial precedent. Int. Rev. Law Econ. 23, 405-420.

Hazelton, Morgan L.W., Hinkle, Rachel K., Nelson, Michael J., Available at http:// rachaelkhinkle.com/research/HHN.Elevator.Effect.pdf 2017. The Elevator Effect: How Collegiality Impacts Dissent, Working Paper.

Hettinger, Virginia A., Lindquist, Stefanie A., Martinek, Wendy L., 2004. Comparing attitudinal and strategic accounts of dissenting: behavior on the U.S. Courts of Appeals. Am. J. Pol. Sci. 48, 123-137.

Kornhauser, Lewis A., Sager, Lawrence G., 1986. Unpacking the court. Yale Law J. $96,82-117$

Legarre, Santiago, 2011. Precedent on Argentine Law. Loyola Law Rev. 57, 781-791.

McCormick, Peter J., 2012. 'Was it something I said?' Losing the majority on the modern Supreme Court of Canada, 1984-2011. Osgoode Hall Law J. 50, 93-128.

Muro, Sergio, Chehtman, Alejandro, Silva Mendez, Jorge, Amaya Duran, Nelson, 2018. Testing representational advantage in the Argentine Supreme Court. J. Law Courts 6, 1-23.

Naurin, Daniel, Stiansen, Ǿvind, 2016. Judicial Dissent and Compliance with the Inter-American Court of Human Rights, Working Paper, on file with the authors.

Niblett, Anthony, Yoon, Albert H., 2015. Judicial disharmony: a study of dissent. Int. Rev. Law Econ. 42, 60-71.

Posner, Richard A., 1985. The Federal Courts: Crisis and Reform. Harvard University Press, Cambridge.

Raffaeli, Rosa, European Parliament document, available at http://www.europarl. europa.eu/studies 2012. Dissenting Opinions in the Supreme Courts of the Member States.

Salamone, Michael F., 2013. Judicial consensus and public opinion: conditional response to Supreme Court majority size. Polit. Res. Q. 20, 320-334.

Shavell, Steven, 1995. The appeals process as a means of error correction. J. Legal Stud. 24, 379-426

Stack, Kevin, 1996. The practice of dissent in the Supreme Court. Yale Law J. 105, 2235-2259.

Sunstein, Cass, 2015. Unanimity and disagreement on the Supreme Court. Cornell Law Rev. 100, 769-823.

Vitale, David, 2014. The value of dissent in constitutional adjudication: context-specific analysis. Rev. Constitut. Stud. 19, 83-108.

Wahlbeck, Paul J., Spriggs II, James F., Maltzman, Forrest, 1999. The politics of dissents and concurrences on the U.S. Supreme Court. Am. Politics Res. 27, 488-514.

Walker, Thomas G., Epstein, Lee, Dixon, William J., 1988. On the mysterious demise of consensual norms in the United States Supreme Court. J. Polit. 50, 361-389.

Wood, Diane, 2012. When to hold, when to fold, and when to reshuffle: the art of decision making on a multi-member court. Calif. Law Rev. 100, 1445-1477.

Wooldridge, Jeffrey M., 2010. Econometric Analysis of Cross Section and Panel Data. MIT press, Cambridge, MA.

Zink, James R., Spriggs II, James F., Scott, John T., 2009. Courting the public: the influence of decision attributes on individuals' views of court opinions. J. Polit. 71, 909-925.

\footnotetext{
51 In those cases where the majority made a reference, we traced the opinion the
} majority referenced to identify the type(s) of Arbitrariedad invoked. 